\title{
How Adenauer Lost Power: Understanding Leadership Rivalry and Succession Conflict in Political Parties
}

\section{Paul 't Hart}

To cite this article: Paul 't Hart (2007) How Adenauer Lost Power: Understanding Leadership Rivalry and Succession Conflict in Political Parties, German Politics, 16:2, 273-291, DOI: 10.1080/09644000701358932

To link to this article: https://doi.org/10.1080/09644000701358932

Published online: 18 Jun 2007.

Submit your article to this journal

Щ Article views: 171

Q View related articles $\asymp$

4 Citing articles: 3 View citing articles 


\title{
How Adenauer Lost Power: Understanding Leadership Rivalry and Succession Conflict in Political Parties
}

\author{
PAUL 'T HART
}

In this article, we reconstruct and interpret the Adenauer-Erhard leadership rivalry in the CDU. This leadership struggle culminated in Erhard replacing Adenauer in 1963 and Adenauer's continued 'guerrilla' warfare against Erhard's leadership, which was one of the contributing factors to the brevity of Erhard's tenure. The case is of intrinsic historical interest but also provides a muster for recent and ongoing leadership succession predicaments in governing parties in Germany and elsewhere. The article presents a conceptual framework of party leadership succession, and zooms in on the (mis)match between the tactical choices made by the incumbent leader and key succession candidates as a key factor explaining the nature and impact of successions. The framework is then applied to the case, and the implications of the findings are placed in a broader comparative context.

\begin{abstract}
'Der Dicke schafft's net' (The fat man can't hack it), Konrad Adenauer disparaging his soon to be successor as German Chancellor and CDU party leader, Ludwig Erhard.

'Hauptsache, et is einer wech' (The main thing is that someone has left), Konrad Adenauer's response to the resignation of Ludwig Erhard as West German Chancellor in November 1966.
\end{abstract}

\section{PARTY LEADERSHIP SUCCESSION PREDICAMENTS}

However good and powerful they may be, all leaders have a limited 'sell-by' date. Political power can never be monopolised indefinitely or unconditionally. However steep the summit of the political hierarchy may be, a leader must maintain sufficient support among the crucial power centres in the society he is governing. Any political leader serves at the mercy of powerful interest groups: his extended family, his ethnic clan, business leaders, the military, party elders, ideological or regional factions within the party, and so on. When these power centres lose faith in a leader, envy him his success, or sense that his once iron fist is weakening, sooner or later his position will be on the line.

In theory, democracies provide intelligent institutional rules for periodic leader succession, yet, as Michels and later theorists imply, ${ }^{1}$ in practice many successions are not the product of election results. Moreover, many leadership successions do not unfold 
particularly smoothly. They often constitute a major political problem for the party and the individuals concerned. They involve considerable risks for all involved and they may have ramifications beyond the personal well-being and political power of the individual protagonists. The parties, governments and polities involved may experience shocks, setbacks, boosts and turning points on the occasion of, if not due to, particular leader succession dramas. This being the case, why then is it that some transitions are so conflict-ridden and catastrophic while others unfold so smoothly and successfully?

A transition that had all the hallmarks of a conflict-ridden and ill-fated succession was the one that saw Ludwig Erhard replace Konrad Adenauer as West German Chancellor in October 1963. Adenauer ruled well beyond his 87th birthday - a rare feat in post-war Western Europe. More importantly, it was the first handover of chief executive power at the federal level in post-war Germany. In this still nascent post-fascist democracy nothing could yet be taken for granted, and Adenauer's rather authoritarian leadership style did not necessarily bode well for his smooth and timely exit from the political stage. As the years of his reign accumulated, many inside the country and abroad began to take the leadership succession issue as a crucial test for the viability of the new democratic political order. They were to witness the most enduring and traumatic political struggle for political leadership that democratic Germany has ever seen. Only the Schröder-Lafontaine rivalry within the SPD of the 1990s comes close, but by then the viability of German democracy was taken for granted and the Chancellorship as such was never seriously at stake once Schröder had assumed it in 1998.

In this article, we reconstruct and interpret the Adenauer-Erhard leadership rivalry, which is of intrinsic historical interest but also provides a muster for recent and ongoing leadership succession predicaments in governing parties in Germany and countries such as Australia (Prime Minister Howard versus Treasurer Costello in the Liberal Party; before them the 1991 coup of Treasurer Keating against incumbent Prime Minister Hawke in the Labor Party), Canada (Prime Minister Chretien who was forced out by the pressure of Treasurer Martin in the Liberal Party), and of course Great Britain (the Blair-Brown saga).

We first present an analytical framework that allows for the systematic study of leadership succession episodes, focusing in particular on the (evolution) of the tactical choices made by the incumbent leader and key succession candidates. It is the degree of alignment between these choices over time that largely determines if successions proceed smoothly or become acrimonious. We then present the case narrative, which will thereafter be interpreted using the framework's analytical tools. In the final section, the Adenauer-Erhard succession rivalry is placed in a broader comparative perspective.

\section{UNDERSTANDING PARTY LEADERSHIP SUCCESSIONS}

Unlike the institutionalised nature of parliamentary elections resulting in the appointment of a new chief executive and cabinet, party leadership successions are mostly ad hoc affairs, frequently rooted in either the incumbent's state of mind, dissatisfaction with the incumbent's performance within the party, and/or in interpersonal or factional power struggles. Given this, it is easy to grasp why comparative studies find that many 
leadership successions are more likely to generate much uncertainty, agony and even trauma within parties and thus may well weaken rather than consolidate or strengthen a party's public support base. $^{2}$

As far as party leadership succession is concerned, there is a considerable pre-existing body of knowledge, but its bulk relates to non-democratic polities and parties, and its relevance for parties in established democracies is perhaps limited. ${ }^{3}$ As far as leadership succession in parties within parliamentary democracies is concerned, there are many largely descriptive case studies of both individual successions and particular parties' leadership succession practices, particularly in the UK. ${ }^{4}$ The number of national, let alone cross-national comparative studies is limited. ${ }^{5}$ The focus in most of this literature is on the nature and impact of (changes in) structural factors in the succession process, particularly different methods of leader (de)selection that particular countries and parties deploy. It shows how various parties have used different selection modes, and when and how they have changed them. These modes include informal cliques of party elders, committees of backbenchers, parliamentary party caucuses, different mixes of parliamentary and extra-parliamentary party delegate voting, as well as the uniquely Canadian figure of the ad hoc leadership convention. ${ }^{6}$

The chief concern driving this research appears to have been with party democracy and a party's internal balance of power, i.e. the question of how different institutional rules of succession distribute the power to control the appointment and dismissal of party leaders among the parties' various organisational strata, and how this affects who gets chosen as leaders and who does not. ${ }^{7}$ This has gained useful insights in its own right, but does little to clarify the pivotal role of the other cluster of variables in the succession equation, namely the role and impact of the chief actors in succession episodes (the incumbent and the succession candidate(s)).

The point of departure for the case study analysis is the conceptual framework depicted in Figure 1. Its main assumption is that the various pieces of the succession puzzle can be modelled as a sequence of factors and moves that co-shape the succession process and its outcomes. Thus, for example, a succession candidate's chances of landing the top job are not only shaped by personal role choice but also driven by personal ambitions, capabilities, style and ties to the incumbent leader and the relevant party power brokers, but also by how this set of personal characteristics 'fits' the nature of the succession context at hand, as well as the role choices and behaviour of the incumbent leader and possible other succession candidates. There may obviously be more factors at play than those stated in Figure 1, but the ones depicted here do capture those that keep recurring in the existing literature.

Succession episodes start when a succession trigger materialises and causes the incumbent, or significant others in the party, to contemplate the prospect of initiating a leadership change. Many circumstances may induce this: ${ }^{8}$ a marked decline in the party's poll ratings, lost elections, a major scandal involving the leader, changes in the leader's health, the reaching of milestone dates or achievements by the leader anything. Figure 1 implies that it is not so much the trigger per se, as the way in which key actors perceive it as an opportunity for action, assess the wider political context in which they operate, and begin to make strategic and tactical choices about possible succession, which shape the course and outcomes of the succession process. 


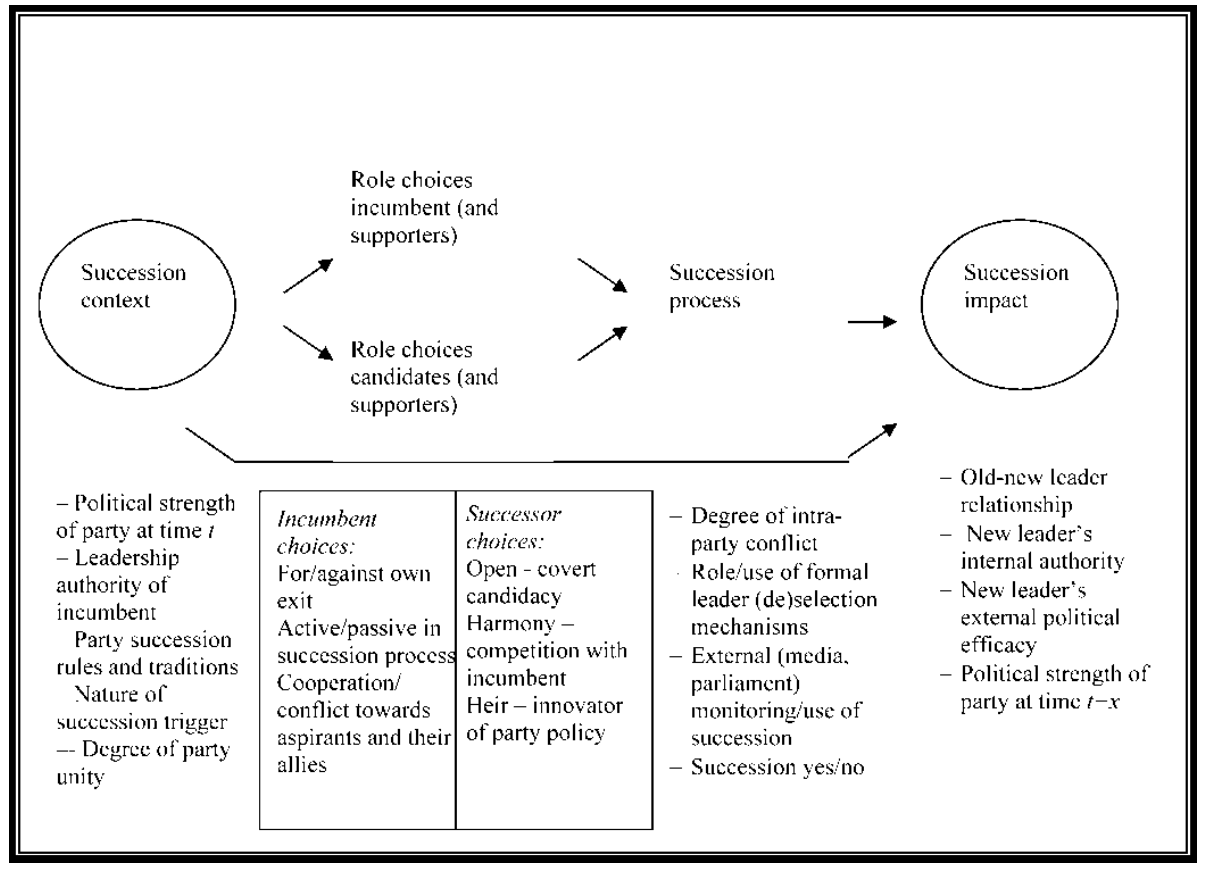

FIGURE 1

MODELLING POLITICAL LEADERSHIP SUCCESSION

The main task for incumbent leaders is to make up their mind if they want to start contemplating the prospect of stepping down at all. Some triggers can be ambiguous and 'fleeting', such as negative poll ratings, and leaders bent on soldiering on in office may be inclined to dismiss their relevance for their own position. This may or not turn out to be an accurate judgement, depending on the responses of other actors such as leading journalists or party power brokers, to these same poll ratings. Once succession is undeniably on the agenda, the incumbent faces a big choice: resist or accept that one's end as leader is nearing. When they embrace the latter, they face a set of tactical choices regarding the candidate selection process and managing their relationship towards the front runner(s) in that process which are quite distinct from those they would face when they embrace the former.

In parallel to the incumbent, potential leadership aspirants will make up their mind in response to the same set of circumstances at the time of the occurrence of the triggering event. They can decide not to run at all, not to run right now, or to begin staging a bid for the leadership. Assuming position $1 \mathrm{~b}$ is taken, they face two major tactical choices: to announce their intentions or not, and work with or against the incumbent and his or her supporters within the party. For example, an aspirant may choose to try and become the designated 'crown prince' by the incumbent leader and/or party elite. This then shapes his further choices: outright repudiation of the incumbent's 
record is then out of the question, and the candidate will have to adopt a posture that promises continuity. Conversely, when an aspirant decides (s)he cannot afford to wait for the incumbent to step down voluntarily, this opens up space to carve out a distinct political profile. Likewise, when an aspirant is clearly opposed to the incumbent's policies or leadership style, (s)he will have to seize the leadership rather than inherit it from the incumbent.

As a succession episode unfolds, the tactical choices of incumbent and chief succession candidate(s) may be more or less aligned. Figure 2 present a simple model

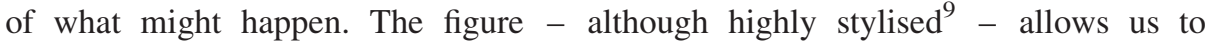
describe and interpret the course of leadership succession episodes as functions of the main players' tactical postures. These postures may be stable throughout, but they may also change over time as a function of contextual influences, changes in the configurations of allies and critics in the party, and changes in the key actors' personal circumstances and beliefs. In the latter part of this paper I shall apply these conceptual tools to the Adenauer-Erhard case, whose main events will now first be recounted.

FIGURE 2

SUCCESSION PROCESSES AS A FUNCTION INCUMBENT'S AND ASPIRANT'S ROLE CHOICES

\begin{tabular}{|l|l|l|}
\hline \multicolumn{1}{|c|}{ Incumbent } & Cooperate with exit & Strive to remain in office \\
$\begin{array}{l}\text { Candidate } \\
\begin{array}{l}\text { Seek harmonious } \\
\text { transition }\end{array}\end{array}$ & Managed transition & Waiting game \\
$\begin{array}{l}\text { Ready to fight for the } \\
\text { leadership }\end{array}$ & Bloodless coup & Power struggle \\
\hline
\end{tabular}

\section{FROM PARTNERS TO RIVALS: ADENAUER AND ERHARD}

On 22 January 1945 the political veteran Konrad Adenauer was elected to be the first president of the newly founded Christian Democratic Party in the British Zone of occupied Germany. Four and a half years later, he became West Germany's first Chancellor. He was 73 at the time, and presented himself deliberately as a transitional figure, an experienced caretaker at the helm of a nation that was stabilising itself, who would soon make way for one of the many much younger ambitious men in the senior ranks of the party. Adenauer even referred his party colleagues to a statement from his doctor that he was in good health for a person his age, and that he could be expected to perform the job for a year or two. ${ }^{10}$ Posing as the duty-bound, somewhat reluctant interim leader was a cunning move, masking the real scope of Adenauer's ambition and stamina. Adenauer quickly consolidated his power, outmanoeuvred all potential rivals, and kept on winning enough votes to make it impossible to throw him out. Presiding over West Germany's remarkable economic resurgence and employing every ounce of his statesmanship to secure its survival on the international stage, Adenauer did not retire as Chancellor until 15 October 1963, and remained party president of the CDU for another two and a half years, finally leaving politics at the age of 90 . 
Adenauer's successor was long-time economics minister Ludwig Erhard, the man who had been pressing him to make way for many years. It was a Pyrrhic victory for Erhard, who would last barely three years in the job. He resigned in November 1966, broken by the office he had coveted for so long. It was a grim triumph for Adenauer. The Adenauer-Erhard rivalry had dominated and at times nearly paralysed the CDU and the government since the late 1950s. Adenauer - deeply convinced that Erhard was not up to the job, certainly not in comparison with himself - had done all he could do prevent Erhard from becoming Chancellor. After the succession that was eventually imposed on him by the power brokers within the party, Adenauer continued to use his power as party president (Erhard did not succeed him in that role until March 1966) to eat away at the political capital of the man who had enjoyed a love affair with much of the German people for nearly 20 years. Adenauer died a few months later. Symbolically, the country was then being governed by a grand coalition between the Christian Democrats and the Social Democrats, one that both Adenauer and Erhard had long sought to prevent.

\section{The Political Background}

Adenauer led a party and a country reeling from the devastating legacy of the Nazi period. Stripped by the Nazis of his office as mayor of Cologne and having lived through two world wars, Adenauer had trodden carefully in the chaotic post-war political environment in the Western occupied zones of Germany. This was a time when the entire political constitution of post-war Germany was fluid, and personal initiative and situational leadership went a long way. Adenauer displayed both, and it earned him the Chancellorship. His political stance blended anti-communism, economic freedom, social conservatism and (West) German statehood embedded in a pro-Western European alliance. Although not a CDU founder, his skilful manoeuvring soon turned him into the undisputed leader of the party, who used his powers of patronage unscrupulously to rid himself of critics and potential rivals. As leader of the government, he soon used article 65 of the new constitution (which gives the Chancellor the exclusive right to determine and be accountable for the main thrust of government policy) to put a lot of distance between himself and 'his' ministers. Adenauer ruled with a velvet-clad iron hand, and was rewarded by the German people in 1953 with 45.2 per cent of the national vote. This enabled him to govern with an expanded majority for his coalition in the Bundestag. He was widely admired by many ordinary citizens as 'father of the nation' and was trusted by the Western allies. He was vilified by a social democratic left, which, however, simply did not have the electoral numbers to topple him.

Adenauer's initial success as Chancellor was in no small measure helped by the resurgence of the West German economy, particularly after 1951. Credit for this remarkable achievement fell to Professor Ludwig Erhard - economic technocrat, jovial pipe smoker, great communicator - who had been drafted into Adenauer's first government as minister of economics. Erhard became the public face of the new economic policy, and he used radio, written press and poster campaigns to get his mantra of a social, yet market-based economy across to the German people. Vehemently opposed at first, Erhard was vindicated when the economy took an upswing after the outbreak of the Korean war, and embarked on a long period of expansion. Erhard soon became the most popular man in West Germany. 
He was far less popular with Adenauer, who had been lukewarm about his appointment in 1949. A meticulously organised, dour realist without illusions about human nature, Adenauer did not take well to the buoyant, self-assured, idealistic, disorganised Erhard. ${ }^{11}$ Adenauer resented Erhard's popularity, believed he was dangerously overconfident in his ability to foretell and control the tide of the economy, disagreed with his free-trading, Anglo-American orientation (Adenauer saw France in a French-led economically integrated Europe as Germany's principal partner) and thought him naïve about world politics. Within cabinet, he left few opportunities unused to cut Erhard down to size, regardless of Erhard's deferential demeanour towards him. Yet it was this man who time and again was put forward by opinion pollsters, journalists and CDU leaders as the self-evident successor to the aging Chancellor.

\section{Towards a Post-Adenauer CDU - Slowly}

According to his biographer Koch, Adenauer 'spent a large part of the last ten years of his life attempting to block Ludwig Erhard's road to the Chancellorship, and then from 1963 onwards - to get him evicted from the Chancellor's office'. ${ }^{12}$ This puts the beginning of the politicking surrounding Adenauer's succession as Chancellor in 1956 about half-way into his 14-year tenure in office. At first sight this seems remarkably early, but the timing was understandable in the context of the times. As described above, Adenauer had risen to power as old man destined to be there only a short while. In that regard, it is more remarkable that it took seven years for the succession issue to be aired. Moreover, 1957 would be an election year, and given Adenauer's advanced age it made sense for CDU leaders to contemplate who would be the one to lead the party into the forthcoming elections. Adenauer indulged them by periodically allowing himself to be drawn into discussions about succession candidates, making sure to mention anyone but Erhard and to keep alternating names of possible heirs. ${ }^{13}$ The people involved were flattered and hopeful for a while, only to seemingly lose favour, causing one of them, finance minister Etzel, to quip that 'everyone aspiring to succeed Adenauer as Chancellor must be suicidal'. ${ }^{14}$ Meanwhile he made sure it stayed at the level of idle speculation, fought the 1957 election himself, and won an absolute majority in the Bundestag. Adenauer was at the zenith of his power in 1957. In the years that followed, he had to endure its gradual erosion. ${ }^{15}$

\section{The Adenauer-Erhard Tandem: Appearance and Reality}

To the German public Adenauer and Erhard were presented as a tandem by CDU propagandists (although Erhard did not formally join the party until just before he became Chancellor): Adenauer guaranteed security and stability at home and respectability abroad, Erhard was the wizard of wealth creation. Adenauer enabled Erhard to do his job, Erhard provided Adenauer with the main direction of the government's economic and social policy. Behind the scenes, their collaboration was much less close than that. The political outsider Erhard initially recognised and respected Adenauer's preponderance, and his communications to him were full of declarations of admiration and loyalty, regardless of Adenauer's mostly cool demeanour towards him.

Right from the start, Adenauer had not been prepared to give Erhard a loose reign. Even in his first government, and well before they developed any of their later policy disagreements, Adenauer refused to indulge Erhard's wish to become a 'superminister' 
in charge of all things economic. ${ }^{16}$ He carefully circumscribed Erhard's portfolio, requiring him to consult and contend with at least three other ministers. Although Adenauer often supported Erhard's visionary liberalisation recipe for economic renewal against critics favouring a more plan-driven approach, this support was never to be taken for granted.

As the years progressed Adenauer became more convinced that Erhard was a zealous, often right and sometimes lucky minister of economics, but that his judgement on the bigger political and foreign policy issues was poor. ${ }^{17}$ Erhard, for his part, very much wanted to be liked by the all-powerful Chancellor, and seemed to crave his approval. When Adenauer belittled him, Erhard chose to look the other way - at least for a long time. However, Erhard cared about one thing more than about his relationship with Adenauer: his economic ideas. And it was on these ideas that he would not compromise with anyone, even Adenauer. And hence over the years a pattern developed of Adenauer getting more irritated with what he saw as Erhard's zealotry and pedantry, and Erhard wrestling hard to uphold his ideas in government policy whilst at the same time aiming to keep workable relations with the stern old man.

It turned into a strain on both of them. Erhard held a trump card, though: his great popularity with the German people. Erhard's unflinching optimism, his bonhomie and his tangible success in getting money back into the pockets of a people haunted by mass destruction and the spectre of starvation made him a formidable 'electoral locomotive'. His appeal got party leaders around the country all excited about the long-term prospects of retaining government, which even Adenauer could not afford to ignore. Moreover, at the time Erhard and his economic philosophy were liked and trusted by the CDU's on-and-off, and often reluctant, coalition partner, the liberal FDP.

\section{Succession Triggers and Initial Role Choices}

Whereas succession talk had been muted and had taken place largely behind closed doors up until the 1957 election, it started swelling as time seemed to be catching up with Germany's chief ruler. As his age became more and more of an issue, with his peers having left the political stage almost everywhere, and German society modernising rapidly due to the very success of his policies, Adenauer seemed more and more a man of the past. Ambitious men within his party began to show signs of impatience with his leadership. Erhard was certainly not the first among them. A policy zealot, he had long displayed no overt interest in striving for the top job, although as early as 1953 he had confided to his long-time assistant Ludger Westrick that he thought the Chancellorship belonged to him in the event Adenauer would step down or die. ${ }^{18}$ It was rather a group of party friends and journalists - soon to be called the 'Erhard Brigade' - that implanted the idea in him and was doing his bidding.

As stated, Adenauer himself pushed a number of people, often discreetly, to consider running: finance minister (as of 1957) Franz Etzel, interior and (as of 1961) foreign minister Gerhard Schröder, and CDU/CSU parliamentary leader Heinrich Krone. Etzel was unpalatable to most of the parliamentary party; not enjoying the high profile that Erhard did, Schröder had some authority, was clearly ambitious for the top job and would engage in various manoeuvres to enhance his chances in the months and years to come. Krone had never held executive office, and was probably more of a stooge candidate to stop Erhard's momentum, a mere signal to his 
increasingly impatient party colleagues that Adenauer was at least willing to think about succession at all. Other ambitious men who cherished hopes of elevation to the Chancellorship included Eugen Gerstenmaier, the chairman of the Bundestag, who was so keen to move on to bigger and better things that he even let himself be drafted by the opposition parties as a possible surprise candidate for Bundespresident; foreign minister Brentano, who had long received the highest scores in opinion polls concerning a future succession; and the young and brash Bavarian CSU defence minister Franz-Josef Strauss. Strauss probably realised that his own chances of succeeding Adenauer were slim, and pushed for a politically weak, transitional figure, from whom he could then take over a few years later. In short, although he was a superior votegetter to all of these potential rivals and was perennially being talked up by his Erhard Brigade friends in the press and within the party, Erhard at that time was by no means the undisputed heir to Adenauer.

\section{The Succession Process: Towards Escalation}

Koerfer puts the beginning of the succession game, and thus the gradual deterioration of the Adenauer-Erhard relationship into open rivalry, during the cabinet formation process following the 1957 election, which returned the CDU/CSU to power with an absolute majority. ${ }^{19}$ In allocating portfolios Adenauer had great difficulty appeasing the various religious and regional factions within his own party. Weeks of manoeuvres, counter-manoeuvres and sometimes heated debate ensued from which Erhard emerged doubly victorious. First, he obtained his much coveted status of superminister of the entire cluster of financial and economic portfolios. Secondly, Adenauer eventually succumbed to concerted fractional and even public pressure to appoint Erhard Deputy Chancellor. Although constitutionally this position carried no weight whatsoever, in the public eye it was understood as the number two spot, the holder of which was one heartbeat away from the leadership of the nation. Adenauer could not bring himself to ever confirm both these positional gains formally to Erhard. The episode held out a lesson for Adenauer: if he wanted to stop this man from taking his job, he would have to find and groom someone more suitable. From then on, Adenauer's search for alternatives to Erhard as his successor intensified, and his attempts to sidetrack him and cut him down to size multiplied.

During spring 1958, the issue was revived in the public arena when a CDU poll comparing succession candidates was published: with 30 per cent preferring him, Erhard led the field of names for the first time. Brentano's standing had decreased sharply following a painful parliamentary defeat he suffered in January $1958 .^{20}$ The increased press speculation on the subject led Erhard to be drawn. In a private conversation with Gerstenmaier, he confessed outright: 'I want to be Adenauer's successor.' Gerstenmaier then assured him that Erhard would have his support, and he kept his word. Probably unknowingly, Erhard had just lost a competitor and gained an important supporter. ${ }^{21}$ The public discussion about the succession subsided, as other issues and controversies gained prominence.

It returned in full force in the first six months of 1959 when Adenauer tried to kick Erhard upstairs, failed, and made a major miscalculation which cost him most of his remaining support within the party. It brought the rift between the two men definitively into the open. ${ }^{22}$ In September 1959, the term of office of Bundespresident Theodor 
Heuss would expire, and the social democratic opposition party SPD put forward a widely respected candidate early that year. Adenauer, never one to hand presents to the opposition, looked around for successors. He took the not entirely selfless hint of Gerhard Schröder to hand the job to Erhard. The very next day, and without consulting him, Adenauer steered an internal party meeting on the topic carefully towards an Erhard candidature. He proceeded to pressure Erhard to consent by phone during a break in the deliberations, making it seem that the meeting had already reached unanimous agreement on him. Erhard was overwhelmed. He had been preparing himself to become the next Chancellor one day, but the presidency was, at least on paper, the highest office of the land, and thus not to passed over lightly. His answer boiled down to an ambiguous 'Yes, but' (or 'No, unless'), and Adenauer tried to force his hand by making the matter public that same night, against Erhard's explicit wishes.

This backfired when it turned out that the CDU parliamentary party was unwilling to let its main hope for the future be shipped off to a ceremonial position. Intricate extrication manoeuvres and heated debates followed, culminating some weeks later in Erhard's withdrawal. The upshot of the affair was that the rivalry was now a matter of public knowledge, with the papers giving voice to sources within and outside the party accusing Adenauer of wanting to 'assassinate his crown prince', as the Welt newspaper put it. ${ }^{23}$ With Erhard out of the race, the Christian Democrats were hard-pressed to come up with a credible alternative candidate who would enjoy wide support. On 7 April, a new, much larger meeting of prominent CDU politicians met and by that time Adenauer had been massaged into considering nominating himself for the job by his devoted and trusted assistant Globke, who, exhausted by years of round-the-clock back-office labour, saw this as an elegant exit option for both his boss and himself.

Adenauer warmed to the idea, daydreaming about an expansive interpretation of the President's constitutional powers which would give him substantive political influence on government policy (despite having effectively denied the incumbent President Heuss just that back in 1949). Ambiguous talk from Krone and others during premeeting consultations had given him the idea that his then preferred succession candidate Etzel stood a good chance of getting broad support from the CDU/CSU parliamentary party. Adenauer duly steered the presidential nomination meeting towards considering his own candidature. Gerstenmaier realised that this was a golden chance, and further solidified Adenauer's commitment by securing him a unanimous endorsement from the meeting. Little attention was paid at the time to Adenauer's insistence that as President he also envisaged having a decisive voice in the appointment of his own successor as Chancellor.

Erhard wasted no time in laying claim to the Chancellorship in a meeting with Adenauer confidante, banker Robert Pferdmenges. When Pfermenges reported back to him, Adenauer instructed him to talk Erhard out of it, and left for his annual vacation in Italy. During his month there, Adenauer had a change of heart. Conversations with among others Schröder made it clear to him that his hope of replacing his self-made Chancellor-centred government by a form of president-centred government was a pipe dream. Now Adenauer realised he had made a mistake, wanted to renege, and needed a pretext to do so.

On 4 June, with Erhard in the US for a ten-day visit, assured prior to his departure by Adenauer that nothing consequential would happen, Adenauer reneged on his 
intention, and stared down an incredulous and largely indignant parliamentary party meeting to remain Chancellor indefinitely. Erhard was seething ('I am done with this man'), but was soon coaxed into having a 'reconciliation meeting' with Adenauer by the skilful Krone. When it took place, Adenauer instead summed up Erhard's flaws and failures. Erhard in turn demanded a public apology. The meeting was cut short, and yet during that afternoon's party meeting, the men shook hands, the matter allegedly settled. Barely one week later, Adenauer resumed the war of nerves by declaring to the New York Times that Erhard was still lacking in political experience and certainly did not enjoy the support of the majority of the CDU/CSU alliance. It triggered an unprecedented mood of rebellion in his own party, which Adenauer again stared down, leaving it to his and Erhard's adjutants to piece together a public exchange of letters that were to signal that the two rivals had finally achieved reconciliation - a thin veneer on what was clearly a deeply damaged relationship.

\section{Entrenched Conflict}

The Adenauer-Erhard rift was not just about the job of Chancellor. It was also a matter of deep policy disagreement, particularly in the realm of foreign affairs. During most of 1959 and beyond, they had an enduring row over European integration, which would pit 'Atlanticists' like Erhard and foreign minister Gerhard Schröder against 'Gaullists' such as Adenauer for years to come. ${ }^{24}$ In June 1958, Charles De Gaulle had returned to power in France and soon put his stamp on French foreign policy. Simply stated, his position was that the nascent movement towards European economic cooperation and social integration would be French- led and evolve around the French-German bilateral axis, or it would not happen at all. Erhard did not like this one bit. For one thing, he was deeply sceptical about any sort of regional economic integration, believing it to be a recipe for protectionism. He was moreover concerned at what he saw as social engineering ambitions that would further diminish individual freedom and distort the innovative, wealth-creating power of market forces. And he was appalled by De Gaulle's antagonism towards the Anglo-Saxon nations, epitomised by De Gaulle's inclination to keep the British outside the nascent EEC. Erhard said all of this publicly in a lecture in Rome on 23 May 1959.

Adenauer was annoyed and forbade Erhard to criticise the EEC in public, a stricture which Erhard duly ignored. In a series of advertisements and lectures during late 1959 and 1960 he came out against EEC, which he saw as a threat to free market competition; this reinforced growing tensions between the two men. ${ }^{25}$ On 30 December 1959, Adenauer even threatened to withdraw Erhard's commission as Deputy Chancellor, but Erhard persevered, knowing Adenauer's position had weakened in the wake of that summer's presidency crisis: the very next day, another giant advertisement arguing against the technocratic threat of the EEC appeared in the Frankfurter Allgemeine Zeitung. ${ }^{26}$

An additional dimension to the relationship became increasingly clear to Bonn insiders: Adenauer not only had political reservations about and policy disagreements with Erhard, he had come to despise him. ${ }^{27}$

[He] hated Erhard's long monologues on economic themes. He resented his sloppy style of dress, and he detested the smell of cigars which always 
surrounded him and the traces of cigar ash on his jackets. He regarded Erhard's liberal consumption of alcohol as morally offensive. And finally he found Erhard's propensity for self-pity unbearable. ${ }^{28}$

And indeed, over the years, Erhard's complaints about all sorts of people complicating his life as economics minister were amply communicated to Adenauer in regular letters to which Adenauer almost always replied with characteristic curtness and intransigence, never missing an opportunity to put Erhard in his place. ${ }^{29}$ By now, Adenauer had stung Erhard so many times that the dislike was mutual; the time of his craving for Adenauer's respect were over.

But Adenauer had to suppress his feelings. He knew full well that he was shackled to Erhard politically. Dropping him from cabinet or openly attacking him would cost Adenauer more than he would gain. Erhard was simply too popular, whilst his own position had weakened. Stepping down was, however, the last thing on Adenauer's mind. In early 1960, he manoeuvred deftly to stave off any attempts to keep him from leading the party into the next year's election, including a masterful self-mocking performance during a parliamentary debate in April uniquely devoted to the age and health of the Chancellor. He also pressed his party colleagues to demonstrate unity, and to keep any internal disagreements out of public view. He assured the late April party conference that when the time for his departure came, 'there would be enough people available to take the helm with strength and vigour'. The plural in this sentence was notable, and it was certainly noted by Erhard, whose own two-hour speech evoked a lengthy ovation. Yet Erhard too had to suppress his feelings: Adenauer was voted back as party president by 427:10 votes, a telling sign of his continued hold on the party. $\mathrm{He}$ had furthermore managed to defy all pressure to commit himself to a date for his departure, and in the months to come he would frequently embark on demonstrations of his physical fitness in order to curb uncertainty about his capacity to keep governing.

The conflict about the succession went underground for most of the remainder of 1960, although periodically the press got word of some of their ongoing policy disagreements. In June there was even a meticulously prepared and well-publicised reconciliation meeting at Adenauer's holiday home in Italy. Erhard had to swallow his pride and sense of entitlement when Adenauer ruled against the two of them campaigning on a joint ticket as leader and 'crown prince' during the next election campaign, which would be much more of a struggle now that the opposition SPD had adopted a much more moderate programme and would be led by a young and popular candidate, Berlin mayor Willy Brandt. The electoral strategists of the CDU were not happy with this. Their polling data showed them how pivotal Erhard would be in the September 1961 election and how ambivalent the electorate was about four more years of the now 85-year-old Adenauer. From December 1960 onwards, Bundestag President Gerstenmaier, campaign leader Kai-Uwe von Hassel, the new party chairman of CDU/CSU's likely post-election coalition partner FDP Eric Mende, and even Adenauer's faithful ally but now 'honest broker' Krone began to press the Chancellor to accept Erhard as his equal in a campaign that would sell them in tandem. This was to signal to the electorate that leadership continuity of party and country would be assured. It took intensive pressure from Krone in particular to get Adenauer to stop resisting the proposed campaign slogan 'Adenauer, Erhard and their team'. ${ }^{30}$ 
The campaign became a triumph for Erhard, who gave 180 speeches mostly to great public acclaim, and a fiasco for Adenauer, who made the crucial mistake of virtually ignoring the building of the Berlin wall, one month before the election date, and proceeded to verbally attack Brandt at a time when Brandt was symbolising the dignified resistance of the people of Berlin against this brutality. The CDU/CSU lost its absolute majority, and Adenauer had to endure that his preferred coalition partner FDP made his own removal from the scene a condition for its cooperation. Likewise, Franz Josef Strauss's CSU campaigned to make Erhard Chancellor of the new government. But it all came to naught: to FDP party leader Mende's dismay, Erhard failed to seize the moment to run against Adenauer when Adenauer asked him and Gersteinmaier to their face if they were considering doing so. ${ }^{31}$ Having won this game of chicken, Adenauer managed to scrape by in the long and tense period of coalition formation. He flirted with the SPD for a while to tone down the intransigent FDP, but failed to reach agreement. Forced to return to the FDP, he had to make one crucial concession: he had to commit himself to stepping down roughly midway - he refused to fix a precise date in the letter he wrote to Krone on 7 November $^{32}-$ through this legislative period.

\section{End Game}

Blamed by his own party for the poor showing at the election, Adenauer was now a lame duck Chancellor. He had made many enemies, for example the highly respected Brentano, whose years in cabinet came to an abrupt end when Adenauer first dumped him as foreign minister (because the FDP wanted this portfolio) and then from cabinet altogether, which Brentano had to hear about on the radio. Adenauer was increasingly isolated, bitter at times, yet more determined than ever to prevent Erhard from succeeding him. He tried what he could to fudge and renege on his commitment, but his party would not let him. The new government did not get off the ground, and in 1962 the FDP withdrew in protest against Adenauer's bullying tactics in the wake of the Spiegel affair, which had already cost Strauss his cabinet seat and had thrown his future career plans thoroughly off-course. ${ }^{33}$ Adenauer tried to punish the FDP by seeking rapprochement with the SPD but was effectively blocked by persistent lobbying of Erhardt and his supporters who were categorically against collaboration with the social democrats. Adenauer was forced back to the FDP, but the reconstructed government was paralysed by mistrust. By late 1962 Adenauer was politically finished as Chancellor, though still not gone.

His war of nerves against Erhard continued. Adenauer left no opportunity unused to belittle and provoke Erhard. Sometimes it bordered on the paranoid, such as when Adenauer accused Erhard by letter of having his assistants spy on cabinet meetings. ${ }^{34}$ He continuously talked down Erhard and tried to push other succession candidates. Adenauer wrestled, but had to go. Things finally came to a head on 22 April 1963 during a meeting of the CDU/CSU leadership devoted to presenting an official nominee for the Chancellorship to the parliamentary party. A day before, Adenauer had met in secret with a number of presumed Erhard critics in the cabinet to get their support for postponing the nomination. It was to no avail. Brentano presided over the meeting, and opened it by saying that as far as he was concerned, there was only one candidate: Erhard. Adenauer interjected that there were in fact 
four: Erhard, Krone, Schröder and Brentano himself. Brentano retorted that he was not running and called upon the others to state their intentions. Krone immediately denied; the ambitious Schröder hesitated initially but when challenged by colleagues to come clean, he withdrew. That left only Erhard, who was duly nominated. The next day, the full parliamentary party meeting endured Adenauer's final attempt to convince his colleagues that Erhard was the wrong choice, and proceeded to vote him in by 159 against 47 with 19 abstentions.

The battle lost, at least momentarily, Adenauer paid a price for all his exertions. During the last months of his reign he suffered a heart attack and was bed-ridden for two weeks, although this remained hidden from the German public. The official succession - the first peaceful handover of power in post-war (West) Germany took place on 15 October.

\section{Post-Succession Skirmishes}

Adenauer had failed to counter the Erhard onslaught, but after stepping down as Chancellor he retained the presidency of his party - and thus the capacity to make Erhard's life as difficult as he possibly could. Erhard long remained untroubled by the veteran's one-man guerrilla war against him. His reign began with high expectations, and he manifested a much more informal, collegial and open leadership style than his predecessor, which was widely heralded. At the 1965 election he managed to recover much of the ground CDU/CSU had lost in 1961. But he did not manage to capitalise on it during the coalition talks with CSU and FDP.

Things began to unravel soon after. For all his personal obsessions against him, Adenauer's judgement about Erhard's unsuitability for the top job proved not altogether unfounded. Particularly in the foreign affairs domain, Erhard was regularly out of his depth against the likes of De Gaulle and particularly Lyndon Johnson. And when his key claim to fame, the strong German economy, began to show problems, Erhard's long-standing belief in the self-correcting capacity of markets was not enough to do the trick. He failed to prevail on his cabinet colleagues to reign in government spending, and his government began running big deficits. His support within the party proved less solid than he had assumed. ${ }^{35}$ Mierzejewski argues moreover that Erhard in his mid-sixties hardly matched the energy and zest that Adenauer had displayed in his late seventies. ${ }^{36}$ He was often tired and spent ever longer and more frequent vacations in his house on Lake Tegern in Bavaria.

When in July 1966 the CDU lost important regional elections in North RhineWestphalia, this was the beginning of the end for Erhard. It became painfully apparent that Erhard, never a party man himself, lacked true support in the CDU. His electoral appeal fading, he lost his usefulness, and potential rivals to his leadership began to stir. Adenauer did little to stop this self-fulfilling prophecy. On the contrary, in interviews he spoke openly against Erhard, to the dismay of the party elite, and parliamentary party leader Barzel went to the old man to reign him in. ${ }^{37}$ Not that this had much effect: Adenauer tried to push Gerstenmaier as the best candidate, but by then he had lost all influence within the party. The latter half of 1966 was rife with forced statements of loyalty ('Erhard is and will remain our Chancellor'), but in the meantime the real talk of the town was about who would succeed Erhard. When the FDP pulled back 
from the coalition, Erhard's attempts to continue with a minority government were doomed to fail. He was finished politically.

\section{INTERPRETING THE ADENAUER-ERHARD SUCCESSION ${ }^{38}$}

This exhausting leadership struggle in the end produced only losers: Adenauer fell off his pedestal, Erhard won a Pyrrhic victory, and the CDU saw its de facto monopoly on government undermined decisively. How did it end up like this? Applying Figure 1's trio of context, role choices and process factors, the following picture emerges.

\section{Contextual Factors}

Clearly, Adenauer's age was a major factor driving the succession issue, giving his eventual departure an air of inevitability. Sheer longevity in office added to the pressure: Adenauer's continued hold on power not only blocked accession to the top of a younger person, it effectively perpetuated a particular political agenda and an autocratic leadership style that were increasingly seen by as being out of tune with the times. Adenauer managed to offset much of this pressure by a variety of devices. He kept on winning elections - the acid test of any party leader's claim on power. He also used his control of the party machine to marginalise internal critics, for example by using his power of appointment to get rid of them and reward loyalists with inner circle positions.

These counteracting mechanisms began to wane when questions arose regarding his continued elect ability - however muted - from 1959 onwards. That the party managed to force Adenauer to accept Erhard as his 'running mate' in the 1961 campaign was a clear sign of the changing balance of power: not only would Adenauer have been strong enough to refuse such a move in 1957, but, more importantly, such a move was not yet contemplated by all but a few within the party's cadre.

Later on, Adenauer's ineffective campaigning and the party's disappointing result at the 1961 election confirmed the now widely held opinion that the party could not afford to fight yet another election with Adenauer as its Chancellor candidate. The party's own pre-election polls clearly revealed the great extent to which Adenauer's popular standing had begun to slip. The FDP's open insistence in 1961 on Adenauer's removal as Chancellor as a condition for its participation in a coalition government with the CDU/CSU played right into this feeling, and provided welcome support to the Erhard Brigade's campaign (although Erhard lacked the political instinct or - as some said - courage to make full use of this external pressure). Adenauer managed to call the FDP's bluff eventually, but at the price of a chaotic coalition formation process and a chronically unstable government, both of which further detracted from his allure.

\section{Role Choices}

Adenauer spent the last few years of his Chancellorship fighting a rearguard battle which ultimately became self-defeating. In terms of Figure 2, Adenauer's posture from 1957 onwards was that he aimed to continue in office as long as he was given the opportunity by the voters (he long assumed he was in full control of his party). In parallel to this posture he adopted another, more hidden one on the selection of 
the eventual successor: he was against Erhard from the start. For a long time fudging the succession issue, yet with the pressure to face it rising steadily, two things happened.

First, Adenauer wavered on the prospect of exiting once: in 1959 he came close to resigning the Chancellorship in favour of becoming Bundespresident. In his mind, this did not mean relinquishing the party leadership at all. It proved a major miscalculation from which he never quite recovered. The unspeakable - Adenauer's departure - had now been spoken by the leader himself. Once he understood that quitting as Chancellor inevitably entailed relegation to the party-political sidelines, his hasty retreat was unimpressive. A public impression began to form of a man who did everything he could to cling to power, even at the price of damaging his party and complicating the process of governing the country. Second, Adenauer stiffened in his resolve to keep Erhard from succeeding him. What at first had been a tightly kept sentiment gradually became a known fact, which even the affable Erhard could not keep ignoring. In short, Adenauer's overall succession posture by and large remained firmly locked into the right-hand side of Figure 2. The case does suggest that in future analyses a distinction may have to be made in incumbent attitudes towards two related yet distinct components of the succession question: exiting yes or no at a given time, and the choice of the successor. Adenauer briefly moved to the left on the former in 1959, retreated, and then was practically forced to move again in 1961, but he never moved an inch on the successor issue. If anything, he hardened: initially he preferred certain people over Erhard, later on his frantic search for alternatives suggested that anybody but Erhard would do.

The key to Erhard's convoluted pattern of evolving his role choice from the upper to the lower half of the successor's field in Figure 2 lay in his personality: his chronic dislike of, and inability to participate in, the kind of hardball politics that Adenauer practised, and his long-maintained desire to be liked and respected by the Chancellor. In combination, these two characteristics enabled him, unwittingly, to absorb the cumulative, incessant stream of condescension, restraint, disagreement, belittling and even loathing that Adenauer sent his way - directly, mostly in personal correspondence, and indirectly, through whispering campaigns, tactical manoeuvres, in speeches and even in press interviews. Erhard either did not see much of it, or preferred to adapt benign interpretations where a sense of realism would have dictated otherwise. Or, as Adenauer came to believe, Erhard was simply so consumed by his own desire to become Chancellor that he absorbed rather than resisted it (and meanwhile having his friends in the party and the media doing much of his bidding for him). To be sure, some of the worst strictures and insults infuriated Erhard at times, but his anger never lasted long - and Adenauer probably sensed that he could get away with as much as he did. Erhard did threaten to resign at various times, which did not cut much ice with Adenauer, but not so much as part of the succession struggle as in the context of ongoing policy disputes within the government.

\section{The Succession Process}

However much the tension surrounding the succession issue was growing as the two men gradually became set on a collision course, Adenauer could ill afford to fire Erhard or really provoke him to resign. Erhard was simply too popular, first within 
the country and later on more and more among the party bosses, whom he had always eschewed but that saw him as the vote winner they needed to hold on to government in a post-Adenauer era. By the end of the 1950s, as Adenauer's own position became less and less omnipotent and succession talk was on the rise, Erhard's star had risen too high for Adenauer to shoot it down without serious consequences to himself.

The uneasy partnership between the "dissimilar founding fathers" ${ }^{39}$ of post-war Germany persisted against the odds well into the 1960s, increasingly driven by both men's determination not to let the other win. The process unleashed forces that neither could control. It was precisely because of this long fight for survival that Adenauer ended up having to accept as his successor a man he saw as completely unsuitable for the job and whom he disliked. By the time he was forced into announcing his departure roughly two years in advance, his standing within party and country had declined so much that he had little clout left to manipulate the party's successor selection process, with the April 1963 meetings the shrill culmination of his demise.

A remarkable feature of Adenauer-Erhard rivalry is that it in some sense continued well after the succession had taken place. Usually, former leaders give up and retreat into the background. Not Adenauer. Although he did not escape the fate of any former leader - the painful awareness that one's influence is evaporating at alarming speed he did what he could to bring about Erhard's demise. Time and again, Erhard was forced to face the fact that his predecessor was still able to fire shots at him, initially drawing on his continued incumbency of the CDU's party presidency, and later when Erhard was becoming more vulnerable - by talking to the press. Whereas some other victims of party coups against their leadership have done the same Australia's John Gorton and Bob Hawke being two key examples - few if any had enough stature left to have an impact.

Adenauer did. The combined weight of his dogged resistance prior to succession and his sabotage campaign following it, produced a self-fulfilling prophecy: Erhard's energy was on the wane by the time he became Chancellor, and despite initial electoral success his Chancellorship imploded quickly afterwards. Observers agree that the exhausting succession battle and the continued enmity of his predecessor were among the key factors sealing Erhard's fate as a mere transitional Chancellor. ${ }^{40}$

\section{CONCLUDING REMARKS}

The epic Adenauer-Erhard leadership struggle remains unique in post-war German politics for its sheer duration and its debilitating effects on the key individuals, their party and the government. Yet if one looks across the border, it is not difficult to find instances of leadership struggles which evolved nearly precisely according to the same scenario: long-standing political allies holding the two top jobs in government getting locked into a succession struggle, with the incumbent leader withdrawing from initial intimations or even formal agreements concerning a timely departure in favour of the 'crown prince'; and the 'crown prince' gradually losing his patience and moving from a collaborative towards a confrontational posture. In the resultant showdown, tenacious and resourceful incumbents can delay, but never prevent their own downfall. But they can raise the price of power for their succeeding rivals to such an extent that their chances of evolving from a 'usurper' into a 'great leader' are strongly diminished. 
Paul Keating in Australia and particularly Paul Martin in Canada won their succession battles, but never managed to eclipse their predecessor's longevity and reputation as leader of party and country. This does not bode well for the future of Australian and British leadership aspirants Peter Costello and Gordon Brown: at the time of writing, both their succession struggles are back at the 'waiting game' stage. Brown looks as though he can succeed Blair short of a party coup, whereas Costello's ambition is still thwarted by the continued ambition and electoral appeal of his partner-cumrival John Howard. If and when they finally make it to the top, the case study presented here suggests that both may have a very hard time staying there and performing successfully.

\section{NOTES}

1. R. Michels, Political Parties: A Sociological Study of the Oligarchical Tendencies of Modern Democracy (New York: Free Press, 1962[1911]); P. Calvert (ed), The Process of Political Succession (London: Sage, 1978).

2. P. Calvert (ed.), The Process of Political Succession (London: Sage, 1987); R. Punnett, Selecting the Party Leader: Britain in Comparative Perspective (London: Wheatsheaf, 1992); J.W. Davis, Leadership Selection in Six Western Democracies (Westport, CT: Greenwood, 1998); F. Bynander and P. 't Hart, 'The Politics of Party Leader Survival and Succession: Australia in Comparative Perspective', Australian Journal of Political Science 42/1 (2007), pp. 47-72.

3. Cf. F. Bynander, and P. 't Hart, 'When Power Changes Hands: The Political Psychology of Leadership Succession in Democracies', Political Psychology 27/5 (2006), pp.707-30.

4. P. Norton, 'Choosing a Leader: Margaret Thatcher and the Parliamentary Conservative Party', Parliamentary Affairs 43/3 (1990), pp.249-59; K. Alderman and N. Carter, 'The Labour Party Leadership and Deputy Leadership Elections of 1994', Parliamentary Affairs 48/4 (1995), pp.438-55; K. Alderman, 'The Conservative Party Leadership Election of 1997', Parliamentary Affairs 51/1 (1998), pp.1-16.

5. P. Weller, 'The Vulnerability of Prime Ministers: A Comparative Perspective', Parliamentary Affairs 36/1 (1983), pp.96-117; idem, 'Party Rules and the Dismissal of Prime Ministers', Parliamentary Affairs 47/2 (1994), pp.133-43; Calvert, The Process of Political Succession; Davis, Leadership Selection in Six Western Democracies.

6. K. Günther, Der Kanzlerwechsel in der Bundesrepublik: Adenauer - Erhard - Kiesinger (Hannover: Verlag für Literatur und Zeitgeschehen, 1970); Punnett, Selecting the Party Leader; J.C. Courtney, Do Conventions Matter? Choosing National Party Leaders in Canada (Montreal: McGill-Queens University Press, 1995); L. Stark, Choosing a Leader (London: MacMillan, 1996); Davis, Leadership Selection in Six Western Democracies; T. Quinn, 'Electing the Leader: The Brtish Labour Party's Electoral College', British Journal of Politics and International Relations 6/3 (2004), pp.333-52; idem, 'Leasehold or Freehold? Leader-Eviction Rules in the British Conservative and Labour Parties', Political Studies 53/4 (2005), pp.793-815.

7. L. LeDuc, 'Democratizing Party Leadership Selection', Party Politics 7/3 (2001), pp.323-41.

8. See Bynander and 't Hart, 'When Power Changes Hands'.

9. The model is, as always, a simplification. It deals with only one dyad, but in reality there may be more potential successors, and the resultant succession process is more difficult to model because of the anticipation and reaction effects that occur among multiple players when one of them shifts position.

10. K. Adenauer, Erinnerungen, Band I (Stuttgart: DVA, 1965), p.228.

11. A. Metz, Die Ungleichen Gründervater: Adenauer's und Erhard's Langer Weg an die Spitze der Bundesrepublik (Konstanz: Universitätsverlag Konstanz, 1998).

12. P. Koch, Konrad Adenauer: Eine Politische Biographie (Reinbek: Rowohlt, 1985), p.452. All quotes have been translated by the authors from German sources.

13. Ibid., p.451.

14. Ibid., p.454; cf A. Baring, 'Sehr verherter herr Bundeskanzler'. Heinrich von Brentano im Briefwechsel with Konrad Adenauer, 1949-1964 (Hamburg: Hoffman und Campe, 1974).

15. H.-P. Schwarz, Adenauer. Der Staatsmann: 1952-1967 (Stuttgart: DVA, 1991); G. Knapp, Kanzler: Die mächtigen der Republik (Munich: Bertelsmann, 1999), pp.78-80. 
16. Metz, Die Ungleichen Gründervater; K. Sontheimer, Die Adenauer-Ära: Grundlegung der Bundesrepublik (München: DTV, 2003).

17. Schwarz, Adenauer.

18. D. Koerfer, Kampf ums Kanzleramt: Erhard und Adenauer (München: Propyläen, 1998 [orig. edn. 1987]), pp.175-6.

19. Ibid., p.184.

20. Baring, 'Sehr verherter herr Bundeskanzler'.

21. Koerfer, Kampf ums Kanzleramt, p.193.

22. Koerfer, Ibid., pp.233-383.

23. Cited by Koch, Konrad Adenauer, p.465.

24. R. Barzel, Ein Gewagtes Leben: Erinnerungen (Stuttgart: Hohenheim, 2001), p.206; A. Baring and G. Schöllgen, Kanzler, Krisen, Koalitionen (Berlin: Siedler, 2002), p.78.

25. Later on, Erhard would lobby incessantly for British inclusion, to De Gaulle's and Adenauer's growing fury. After the Franco-German cooperation treaty was negotiated in summer 1962, De Gaulle pressed ahead in January 1963 imposed a unilateral veto on British entry to the EEC one week before the Franco-German treaty was to be signed. Erhard argued in cabinet against signing the treaty under these circumstances. He managed to gain his colleagues' support, giving Adenauer a rare defeat at the cabinet table. He and the Erhard Brigade campaigned to have the Elysee treaty's preamble revised. On 5 February 1963 the Süddeutsche Zeitung published an interview with Erhard in which he regretted the French veto against Britain and argued emphatically that West Germany should strive to maintain its close relations with the UK and the US. In that interview he stated publicly for the first time that he was prepared to take over the Chancellorship. Adenauer was seething, but by that time he was almost out of the game and Erhard was almost Chancellor.

26. Koerfer, Kampf ums Kanzleramt, pp.421-2.

27. A.C. Mierzejewski, Ludwig Erhard. Der Wegbereiter der sozialen Marktwirtschaft. Biografie (Berlin: Siedler, 2005), pp.268-70.

28. Ibid., pp.269-70.

29. Koerfer, Kampf ums Kanzleramt.

30. Ibid., p.547.

31. Mierzejewski, Ludwig Erhard, p.276; Koch, 1985: 481; H.-O. Kleinmann, Geschichte der CDU, 1945-1982, edited by G. Buchstab (Stuttgart: DVA, 1993), p.186.

32. Kleinmann, Geschichte der CDU, 1945-1982, p.186.

33. Der Spiegel had published highly critical articles about defence minister Strauss, who had subsequently had its chief editors arrested and its offices searched on flimsy charges. Adenauer supported Strauss's actions - in the process condoning Strauss's blatant by-passing of the FDP's interior minister normally responsible for police matters - and the two become the chief target of mass demonstrations, parliamentary uproar, and FDP indignation.

34. Koch, 1985, p.491.

35. Kleinmann, Geschichte der CDU, 1945-1982, pp.240-41.

36. Mierzejewski, Ludwig Erhard, p.285.

37. Barzel, Ein Gewagtes Leben, pp.199-200.

38. Günther (Der Kanzlerwechsel in der Bundesrepublik) is the key source that gives a systematic explanatory account of the case and compares it to the subsequent Erhard-Kiesinger transition, which was, however, of a completely different kind.

39. Metz, Die Ungleichen Gründervater.

40. Mierzejewski, 2005, pp.316-17. 